\title{
Corrigendum
}

\section{Glutathione depletion sensitizes cisplatin- and temozolomide-resistant glioma cells in vitro and in vivo}

\author{
CRR Rocha, CCM Garcia, DB Vieira, A Quinet, LC de Andrade-Lima, V Munford, JE Belizário and CFM Menck
}

Cell Death and Disease (2015) 6, e1727; doi:10.1038/cddis.2015.101; published online 16 April 2015

Correction to: Cell Death and Disease (2014) 5, e1505; doi:10.1038/cddis.2014.465; published online 30 October 2014

Since the publication of this paper the authors have noted that Figure $2 \mathrm{a}$ is incorrect it was mistakenly exchanged in the final
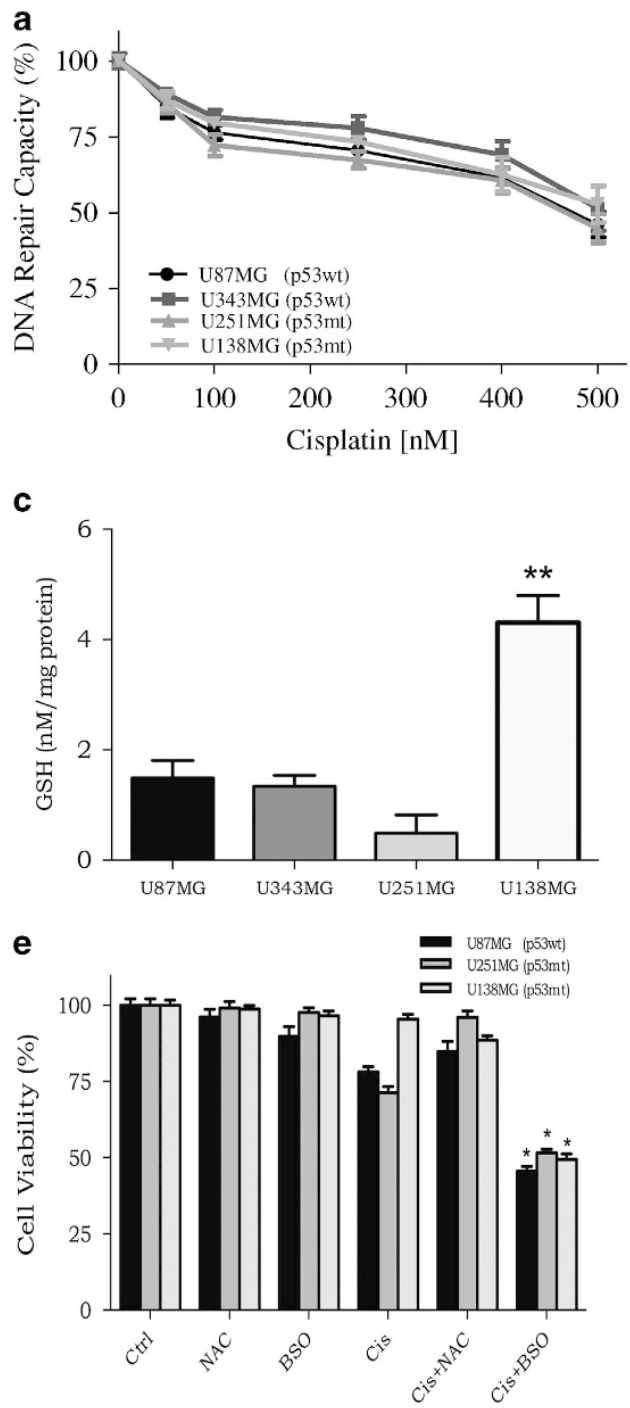

article. This has now been rectified and the corrected article appears online together with this corrigendum.

The authors would like to apologize for any inconvenience this may have caused.
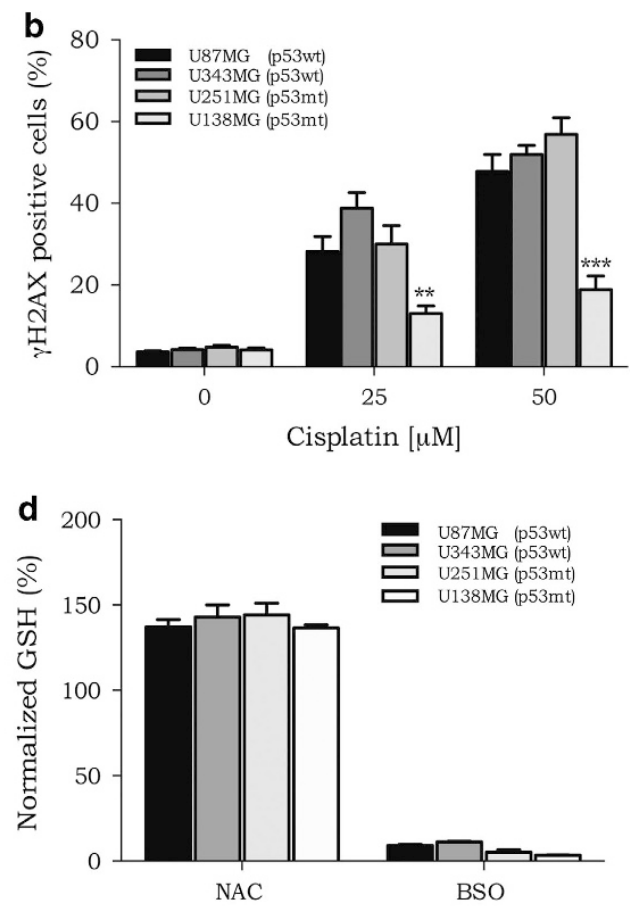

$\mathbf{f}$

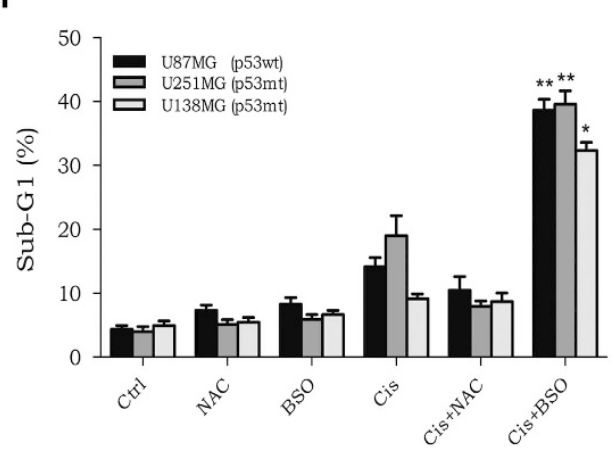

Figure 2 DNA repair capacity and GSH concentration in glioma cell lines. (a) HCR assay with a luciferase plasmid treated with increasing doses of cisplatin. (b) Quantification of $\gamma \mathrm{H} 2 \mathrm{AX}$-positive cells upon cisplatin treatment, as detected by flow cytometry. (c) Quantification of the basal intracellular GSH concentration in the four glioma cell lines. (d) Quantification of the intracellular GSH concentration after BSO or NAC incubation. (e) Cellular viability, as determined by the XTT assay, in cells treated with BSO or NAC combined with cisplatin. (f) The percentage of apoptotic cells, as measured by the sub-G1 population, after treatment with cisplatin in combination with BSO or NAC. Values are mean \pm S.E.M. of three independent experiments, ${ }^{\star} P<0.05,{ }^{* \star} P<0.01$ and ${ }^{* \star *} P<0.001$ 